\title{
STAVOVI RODITELJA I RAZREDNIKA O OBLICIMA, UČINCIMA I TEŠKOĆAMA PARTNERSKIH ODNOSA IZMEĐU OBITELJI I ŠKOLE
}

\author{
Mirjana Knežević \\ Dječji vrtić Lastavica u Osijeku, Osijek, Republika Hrvatska
}

\begin{abstract}
Sažetak
Obitelj i odgojno-obrazovne ustanove dominantna su okruženja djeteta i zato je njihovo partnerstvo prijeko potrebno. Dok suradnja podrazumijeva pokušaj zadovoljavanja interesa obiju strana, pojam partnerstva, koji se danas sve više koristi, ističe ravnopravnost strana i toleranciju. $U$ literaturi se ističu određeni učinci toga partnerstva kao što su bolji akademski uspjeh djece, bolji odnos djece prema školi te učiteljima i nastavnicima, osnaživanje obitelji te rasterećenje djece.

U empirijskom dijelu cilj je bio utvrditi koji oblik odnosa, tradicionalni ili partnerski, njeguju roditelji i razrednici, vide li prednosti partnerskoga odnosa za djecu, odnosno učenike te ispitati njihove stavove o teškoćama ostvarenja partnerskoga odnosa. Istraživanje na uzorku od 72 roditelja i 18 razrednika provedeno je tijekom rujna i listopada 2017. u Ugostiteljsko-turističkoj školi u Osijeku. Pri provedbi istraživanja koristio se postupak anketiranja. Podatci istraživanja obrađeni su deskriptivnom statistikom, prikazani su grafički i tablično i interpretirani su. Dobiveni rezultati pokazuju kako, unatoč teorijskom zagovaranju partnerskoga odnosa, roditelji i razrednici i dalje prakticiraju tradicionalan odnos iako obje skupine uzorka vide prednosti partnerskoga odnosa za djecu/učenike. Također, razrednici smatraju kako roditelji surađuju sa školom samo kada je to neophodno za daljnje obrazovanje njihova djeteta. Ispitivanjem stavova roditelja i razrednika utvrđeno je kako ne uočavaju teškoće partnerskih odnosa.
\end{abstract}

Ključne riječi: partnerstvo, roditelji, razrednici, učenici

\section{UvoD}

Tema partnerstva između obitelji i škole dio je školske pedagogije. Tom su se temom pedagozi bavili još u davna vremena pokušavajući dokazati njezine pozitivne učinke na dječji razvoj i akademski uspjeh (Kolak, 2006).

Do polovice prošloga stoljeća njegovao se tradicionalni pristup u kojemu su roditelji uglavnom samo prisustvovali roditeljskim sastancima te su ispunjavali odluke učitelja/nastavnika. Tradicionalna orijentacija jest odnos u kojem roditelji prepuštaju odgovornost za obrazovanje djece školi, a škola ne očekuje izravnu uključenost roditelja u život škole. Dakle, ciljeve određuje škola i o njima samo izvješćuje roditelje. Komunikacija s roditeljima rijetka je, uglavnom ju inicira škola i usmjerena je na određene probleme (Pahić, Miljević-Riđički i Vizek Vidović, 2010). Međutim, jačanjem demokracije i povećanjem stupnja obrazovanosti roditelja, javlja se zahtjev za aktivnim sudjelovanjem roditelja u radu škole. To dakako ima smisla jer prema Bronfenbrennerovoj teoriji ekologije ljudskoga razvoja dijete se prvo razvija u mikrosustavu gdje se nalaze njegovi roditelji, a kako raste, dijete se uključuje u makrosustav, to jest različite ustanove kao što su vrtići i škole. Samim time potrebna je komunikacija između tih dvaju sustava jer $s$ jedne strane roditelji najbolje poznaju svoje dijete, a s druge strane dijete se ne 
može shvatiti bez promatranja svih sustava u kojima ono egzistira (Bronfenbrenner, 1986). Partnerstvom obitelji i odgojno-obrazovne ustanove obiteljski se odgoj želi približiti institucionalnom i obrnuto jer ta suradnja kod djece pojačava osjećaj sigurnosti i vlastite vrijednosti.

Tijekom godina javljali su se različiti termini kojima se htjela objasniti važnost uključenosti roditelja u rad odgojno-obrazovne ustanove i zato je bitno napraviti distinkciju između dvaju najfrekventnijih pojmova, a to su suradnja i partnerstvo. Suradnja znači nižu razina odnosa, to jest podrazumijeva hijerarhijske odnose u kojima je odgojno-obrazovna ustanova u nadređenom položaju. Komunikacija između obitelji i osoblja ustanove površna je i uglavnom se ostvaruje samo kada se kod djeteta pojave poteškoće. Takvom se razinom odnosa ne mogu postići značajne promjene. $S$ druge strane, partnerstvo počiva na ravnopravnim odnosima, dijeljenju informacija, aktivnome slušanju te međusobnom poštovanju. Obitelj i odgojno-obrazovna ustanova dva su povezana sustava, a u skladu s time roditelji su uključeni u rad ustanove, dok je osoblje ustanove osposobljeno za izgradnju i održavanje partnerskih odnosa (Kosić, 2009).

Od partnerskih odnosa roditelja i škole najviše profitiraju sama djeca jer postižu bolji akademski uspjeh i osjećaj vlastite vrijednosti (Rosić i Zloković, 2003). Kultura partnerskih odnosa pomaže i u promicanju socijalnog i emocionalnog razvoja djece (Škutor, 2014). Prikladno organizirana suradnja između obitelji i škole omogućuje bolje razumijevanje učenika od strane roditelja i nastavnika, postizanje dogovora oko najboljeg odgojno-obrazovnog pristupa te kreiranje prave odgojno-obrazovne klime u obiteljskom domu i u školi. Roditelji dobivaju osjećaj učinkovitosti jer pridonose dječjem razvoju (Jukić, 2015), a bliski odnosi s ustanovom koju dijete pohađa jačaju samu obitelj (Epstein, 2001).

Teachers of the Szybinski High School in Cieszyn and Psychologists from the Psychological and Pedagogical Counselling Centre in Cieszyn (22. rujna 2017.) govore o konkretnim i čestim problemima koji se pojavljuju u odnosu između obitelji i škole (Tablica 1.).

Tablica 1. Teškoće u suradnji roditelja i škole

\begin{tabular}{|l|l|}
\hline \multicolumn{1}{|c|}{ Nastavnici } & \multicolumn{1}{c|}{ Roditelji } \\
\hline - nedostatak vremena & - nedostatak vremena \\
- osjećaj da ih druga strana ne sluša & - osjećaj da ih druga strana ne sluša \\
- sumnja da razgovor može nešto promijeniti & - sumnja da razgovor može nešto promijeniti \\
- osjećaj nedostatka pravog utjecaja na & - strah da bi razgovor s učiteljem/nastavnikom \\
ponašanje roditelja prema njihovoj djeci & mogao imati negativan utjecaj na tretman \\
- osobno iskustvo ili iskustvo drugog & djeteta \\
učitelja/nastavnika o nedostatku učinka & - nedostatak povjerenja \\
suradnje s roditeljima ili roditeljsko & - nedostatak pravog osjećaja podrške od \\
podcjenjivanje učiteljevog/nastavnikovog & učitelja/nastavnika \\
uloženog truda & - strah od slušanja „loših vijesti“ o djetetu, a \\
- osjećaj da problem nije u učeniku, već u & time i smanjenje njihove roditeljske \\
roditelju i učitelju/nastavniku & vrijednosti \\
- strah od javnog nastupa & - ne osjećaju se dobrodošlo, vremenski pritisak, \\
- objektivne teškoće u organizaciji sastanka & loša organizacija sastanaka \\
(primjerice nedostatak vremena i prostora za & - ne osjećaju potrebu uključiti se u školske \\
tihe razgovore ) & aktivnosti \\
- sagorjevanje, odbojnost prema komunikaciji s & - negativna iskustva \\
tzv. „teškim roditeljima“ & \\
\hline
\end{tabular}




\section{Metoda}

\section{Cilj istraživanja}

Cilj je istraživanja utvrditi koji oblik odnosa njeguju roditelji i razrednici, tradicionalni ili partnerski, zatim vide li koristi partnerskoga odnosa za djecu odnosno učenike te doznati smatraju li navedene tvrdnje preprekama za ostvarenje kvalitetnog partnerskog odnosa.

\section{Hipoteze}

S obzirom na cilj istraživanja postavljeno je pet hipoteza koje se odnose na oblike, učinke i teškoće partnerskih odnosa obitelji i škole. Prve dvije hipoteze odnose se na roditelje, druge dvije na razrednike, a peta se hipoteza odnosi i na stavove roditelja i razrednika.

H 1. Roditelji smatraju kako sa školom ostvaruju tradicionalan odnos.

H 2. Roditelji smatraju da partnerski odnos sa školom pozitivno utječe na njihovu djecu.

H 3. Razrednici uočavaju prednosti partnerskoga odnosa s obitelji za učenike.

H 4. Razrednici smatraju kako roditelji surađuju sa školom samo kada je to neophodno za obrazovanje njihova djeteta.

H 5. Roditelji i razrednici smatraju kako postoje teškoće za ostvarenje partnerskoga odnosa obitelji i škole.

\section{Operacionalizacija varijabli}

Temeljna varijabla istraživanja jesu stavovi o partnerskom odnosu između obitelji i odgojno-obrazovne ustanove, odnosno stavovi roditelja i razrednika o toj vrsti odnosa. Partnerski odnos, osim roditeljskih sastanaka i informativnih razgovora, uključuje edukativne radionice, predavanja za roditelje, uključivanje roditelja u proces odlučivanja u školi, uključivanje roditelja u projekte, izlete i aktivnosti te uloga roditelja u povezivanju lokalne zajednice i škole.

Prva hipoteza odnosi se na stavove roditelja o dominirajućem modelu odnosa između obitelji i škole. Tradicionalan odnos podrazumijeva odlazak roditelja na roditeljske sastanke i informativne razgovore. Takav oblik suradnje znači da roditelji nisu uključeni u proces odlučivanja u školi, već su pasivni primatelji informacija.

Druga hipoteza odnosi se na stav roditelja o učincima partnerskoga odnosa između škole i obitelji na njihovo dijete. Prednosti su partnerskoga odnosa za dijete bolji akademski uspjeh, jačanje osjećaja vlastite vrijednosti, promicanje emocionalnog i socijalnog razvoja djeteta, bolje razumijevanje učenika od strane nastavnika te postizanje odgovarajuće odgojno-obrazovne klime za dijete u školi i obiteljskom domu.

Treća hipoteza odnosi se na stav razrednika o učincima partnerskoga odnosa između obitelji i škole na učenika.

Četvrta je hipoteza povezana s prvom, no odnosi se na stavove razrednika o uključivanju roditelja u život škole. Roditeljska suradnja sa školom samo kada je to neophodno za daljnje obrazovanje djeteta odnosi se na opravdavanje sati, pozive razrednika roditeljima zbog negativnih ocjena, problema s ponašanjem učenika u školi te pedagoške mjere koje iz toga proizlaze. To se dovodi u vezu s tradicionalnim oblicima suradnje.

Peta se hipoteza odnosi na teškoće pri ostvarivanju partnerskoga odnosa, a kao tvrdnje ponuđene su teškoće koje se najčešće navode u literaturi: nedostatak vremena, osjećaj da druga strana ne sluša, sumnja da razgovor može nešto promijeniti, negativna iskustva, nedostatak povjerenja i podrške, teškoće s organizacijom. 


\section{Ispitanici}

Istraživanje je provedeno u Ugostiteljsko-turističkoj školi u Osijeku na slučajnom uzorku od 90 ispitanika. Uzorak je obuhvatio 72 roditelja učenika od drugog do četvrtoga razreda te 18 razrednika učenika od drugog do četvrtog razreda. Uzorak je obuhvatio ispitanike obaju spolova, bez obzira na dob, mjesto stanovanja te godine iskustva razrednika. Razrednici su slučajnim odabirom izabrali četiri roditelja iz svakoga razreda, a anketiranje se provodilo tijekom redovitih roditeljskih sastanaka. Roditelji čine $80 \%$ uzorka ispitanika, a razrednici $20 \%$. Što se roditelja tiče, majke čine $62,5 \%$ uzorka ( $N=45)$, a očevi čine $37,5 \%$ uzorka ( $N=27)$. Razrednice čine $72 \%$ uzorka ( $\mathrm{N}=13)$, a razrednici $28 \%$ uzorka $(\mathrm{N}=5)$.

\section{Način provođenja istraživanja}

Istraživanje je provedeno među razrednicima drugih, trećih i četvrtih razreda Ugostiteljsko-turističke škole u Osijeku te među roditeljima učenika drugih, trećih i četvrtih razreda iste škole u razdoblju od početka rujna do kraja listopada 2017. godine. U lipnju 2017. godine izrađen je nacrt pedagoškog istraživanja koji je služio kao polazište za provedbu istraživanja, a koji se vremenom mijenjao i prilagođavao situaciji.

Anketni upitnici za razrednike i roditelje izrađeni su u lipnju 2017. godine te su tijekom kolovoza 2017. godine dobili svoj konačan izgled. Razrednicima su dana četiri anketna upitnika za roditelje te jedan za njih. Roditelji i razrednici svoje su anketne upitnike ispunjavali na roditeljskim sastancima. Ispunjavanje anketnoga upitnika većinom je trajalo do deset minuta.

\section{Postupak i instrumenti prikupljanja podataka te obrada podataka}

Pri provedbi istraživanja koristio se postupak anketiranja, a instrument je bio anketni upitnik za roditeljei anketni upitnik za razrednike, oba nastala za potrebe ovoga pedagoškog istraživanja. Prvi dio anketnoga upitnika sadrži opće podatke o ispitanicima, to jest pitanje o spolu, drugi dio odnosi se na dosadašnja iskustva ispitanika u vezi s odnosom obitelji i škole, a treći dio anketnoga upitnika sastavljen je od skale procjene Likertova tipa.

Podatci prikupljeni anketnim upitnicima korišteni su u svrhu testiranja hipoteza. Metodama grafičkog i tabelarnog prikazivanja prikazana je struktura odgovora na anketna pitanja. Metode deskriptivne analize omogućile su prikaz srednjih vrijednosti (prosječna vrijednost i medijan) te pokazatelje disperzije oko srednjih vrijednosti (standardna devijacija, koeficijent varijacije te kvartilna odstupanja). Razlika u zastupljenosti modaliteta odgovora testira se Hi-kvadrat testom, a kod učestalosti specifičnih odgovora koristi se test razlike u proporciji nezavisnih skupina. Kao pokazatelj slaganja sa skupinom izjava koristi se srednja vrijednost koja se kao nezavisna vrijednost testira Wilcoxon testom u odnosu na odabranu vrijednost.

\section{REZULTATI I RASPRAVA}

\section{Prva hipoteza: Roditelji smatraju kako sa školom ostvaruju tradicionalan odnos.}

Kako bi se utvrdili najčešći oblici odnosa roditelja sa školom, roditelji su trebali između ponuđenih odgovora odabrati dva najčešća oblika komunikacije sa školom u protekloj školskoj godini (2016./2017.). Većina je roditelja (97,2 \%) zaokružila roditeljske sastanke kao dominantan oblik odnosa sa školom, a potom individualne informativne razgovore s razrednikom/com (50\%). Kao čest način komunikacije pokazali su se i telefonski razgovori ( $25 \%$ ) te e-pošta $(20,8 \%)$. Vidno je kako predavanja za roditelje $(5,5 \%)$ te edukativne radionice $(1,4 \%)$ pripadaju 
Mirjana Knežević

najrjeđim načinima kontakata roditelja i škole. Do sličnih je rezultata došao i Centar za obrazovanje i razvoj obrazovanja 2006. godine. Istraživanje je pokazalo kako je suradnja roditelja i škole ograničena na tradicionalne oblike suradnje, dakle na roditeljske sastanke i odlazak na informativne razgovore. Zaključci su navedenoga istraživanjakako su čak i na roditeljskim sastancima roditelji samo pasivni primatelji informacija. Što se tiče netradicionalnih oblika suradnje, edukativnih radionica i predavanja za roditelje, utvrdili su kako su ti oblici nedovoljno razvijeni te kako objema stranama tek predstoji otvaranje za spremnost na takve aktivnosti (Nikčević-Milković, 2008). S navedenim se rezultatima ne slažu rezultati istraživanja koje je proveo Kolak (2006), a jedna od tvrdnji koja je ponuđena roditeljima bila je da su individualni razgovori i roditeljski sastanci dovoljni oblici suradnje roditelja i učitelja. Najviše je roditelja $(39,7 \%)$ reklo kako se uglavnom ne slaže s time.

Kako bi se dokazala važnost roditeljskih sastanaka kao dominantnoga oblika tradicionalnih odnosa roditelja i škole, razrednici su trebali zaokružiti broj održanih roditeljskih sastanaka tijekom protekle školske godine. Rezultati pokazuju kako je 14 razrednika održalo tri roditeljska sastanka $(77,8 \%)$, a četiri su razrednika održala četiri roditeljska sastanka (22,2 \%). Dakle, najveći broj razrednika održao je, sukladno Pravilniku o načinima, postupcima i elementima vrednovanja učenika u osnovnoj i srednjoj školi (Narodne novine, 2010), najmanji propisani broj roditeljskih sastanaka. No potvrda tradicionalnih oblika komunikacije roditelja sa školom dobiva se brojem dolazaka roditelja na održane roditeljske sastanke. Naime, koliko roditelji smatraju roditeljske sastanke važnim oblikom komunikacije sa školom, dokazuje činjenica da je $76,4 \%$ roditelja bilo na trima ili više roditeljskih sastanaka. Što se tiče individualnih razgovora, $44,4 \%$ roditelja tijekom školske godine $2016 . / 2017$. samoinicijativno bilo je na dvama individualnim razgovorima, a tri ili više puta bilo je $22,2 \%$ roditelja.

Pahić i sur. (2010) istraživanjem uključenosti roditelja u život škole utvrdile su kako je škola zvala roditelje na grupne sastanke tri puta pri čemu se gotovo uvijek netko od roditelja odazvao i smatraju potrebnim da ih škola zove na takve sastanke. Roditelji smatraju svojom dužnosti odlazak na takve sastanke. No tvrde kako ih škola tijekom protekle školske godine nije zvala na individualne razgovore što može objasniti relativno malen postotak $(22,2 \%)$ odlaska na tri ili više individualnih razgovora u Ugostiteljsko-turističku školu u Osijeku. Pahić i sur. (2010) objašnjenje vide u uobičajenoj razredničkoj praksi pozivanja na individualne razgovore samo roditelje koji rijetko dolaze u školu, a čija djeca pokazuju određene oblike neprimjerenoga ponašanja ili probleme u učenju.

Nadalje, roditeljima su ponuđene tvrdnje na koje su mogli zaokružiti 1(ne slažem se),2(ni slažem se ni ne slažem se, ne znam) ili 3 (slažem se). Tvrdnje su se odnosile na suvremene oblike suradnje obitelji i škole (Slika 1.). Rezultati pokazuju kako više od polovice roditelja (54,2 \%) nije sigurno, to jest ne znaju bi li voljeli više edukativnih radionica i predavanja za roditelje, a 37,5 $\%$ roditelja bi voljelo imati takvu mogućnost. Također, 47,2 \% roditelja ne zna je li dovoljno uključeno u organizaciju školskih priredbi, izleta i projekata, a njih 33,3 \% smatra da je dovoljno uključeno. Što se tiče uključenosti u odlučivanje o obrazovanju vlastitoga djeteta, $63,9 \%$ roditelja smatra da je dovoljno uključeno, dok 32 \% roditelja ne zna je li dovoljno uključeno.

Lukaš i Gazibara (2010) istraživanjem su utvrdili kako malen broj roditelja želi sudjelovati u organiziranim aktivnostima škole, a sami su roditelji najčešće htjeli organizirati sportske aktivnosti $(27,3 \%)$ te pripremati razne svečanosti $(18,2 \%)$. Autori navode kako nesudjelovanje roditelja u školskim aktivnostima dovodi u pitanje kvalitetu odgojne uloge škole te pedagoške kompetencije roditelja. 


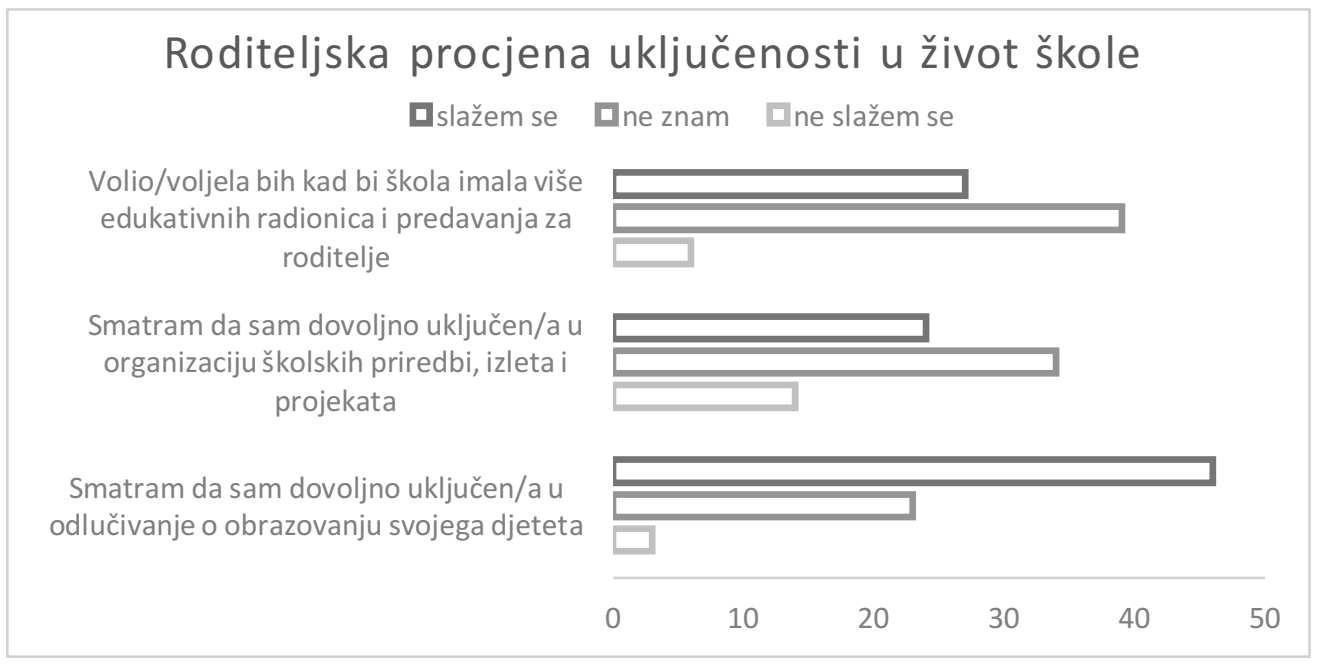

Grafikon 1. Roditeljska procjena uključenosti u život škole

Razrednicima su ponuđene iste tvrdnje kao roditeljima, no iz perspektive razrednika. Na njih su mogli odgovoriti 1 (ne slažem se), 2 (ni slažem se ni ne slažem se, ne znam) ili 3 (slažem se). Tvrdnje su se odnosile na suvremene oblike suradnje obitelji i škole. Njih 66,7 \% razrednika smatra da dovoljno uključuje roditelje u obrazovanje njihova djeteta, a 33,3\% razrednika ne zna čini li to u dovoljnoj mjeri što pokazuje da nijedan razrednik ne misli da nedovoljno uključuje roditelje u suradnju. Zanimljivo je kako polovica razrednika (50 \%) želi organizirati edukativne radionice i predavanja za roditelje, ali smatraju kako roditelji nisu zainteresirani za to. Dovede li se to u vezu s roditeljskom željom za sudjelovanjem u tim oblicima suradnje ( $37,5 \%$ roditelja), može se zaključiti kako među roditeljima i razrednicima postoji ili nedostatna komunikacija ili su davali socijalno poželjne odgovore. Gotovo polovica razrednika nije sigurna uključuje li dovoljno roditelje u organizaciju i realizaciju školskih priredbi i izleta $(44,4 \%)$, njih 38,9\% smatra da ih uključuje u dovoljnoj mjeri, a 16,7 \% razrednika smatra da ne uključuje roditelje onoliko koliko bi trebali.

Zloković (2003) i Maleš (1995) pokazateljem tradicionalnoga pristupa smatraju i komunikaciju roditelja sa školom samo kada je to neophodno za daljnje obrazovanje djeteta ili kada djetetu u školi ne ide baš najbolje, bilo zbog učenja, ocjena ili ponašanja. Tablica 2. prikazuje najčešće razloge komunikacije roditelja sa školom u protekloj školskoj godini. Testiranjem razlika u proporcijama donosi se zaključak da je komunikacija radi opravdavanja sati djetetu statistički značajno najučestaliji razlog komunikacije roditelja sa školom. Zaključak je donesen na temelju empirijske $p$-vrijednosti $(p<0,0321)$. 
Tablica 2. Najčešći razlozi komunikacije roditelja sa školom

\begin{tabular}{|c|c|c|}
\hline & $\mathrm{N}$ & $\%$ \\
\hline - radi opravdavanja sati djetetu & 51 & 68,90 \\
\hline $\begin{array}{l}\text { - kada se dogodi određeni problem (negativne ocjene, neopravdani izostanci, } \\
\text { problemi s ponašanjem) }\end{array}$ & 40 & 54,1 \\
\hline $\begin{array}{l}\text { - tijekom individualnih razgovora na koje dođete samoinicijativno kako biste } \\
\text { provjerili kakvo Vam je dijete u školi }\end{array}$ & 27 & 36,50 \\
\hline - tijekom organizacije i realizacije priredbi ili izleta & 14 & 18,90 \\
\hline - zbog suradnje na određenim projektima (npr. Mi jedemo odgovorno) & 3 & 4,10 \\
\hline $\begin{array}{l}\text { - tijekom sastanaka na kojima ste uključeni u odlučivanje o školskom } \\
\text { kurikulumu te nastavnom planu i programu }\end{array}$ & 0 & 0 \\
\hline
\end{tabular}

Najčešći oblik komunikacije roditelja i škole uvriježeni je i tradicionalni oblik suradnje na roditeljskim sastancima. Također, mali broj dolazaka na individualne razgovore ukazuje na tradicionalan pristup gdje se suradnja s roditeljima traži samo ako dijete pokazuje neprimjereno ponašanje ili probleme s učenjem. Testiranjem razlika u proporcijama kod najučestalijih razloga komunikacije škole i obitelji uočen je statistički najučestaliji razlog, a to je radi opravdavanja sati djetetu.

Iz navedenih rezultata istraživanja može se zaključiti kako se prva hipoteze, roditelji smatraju kako sa školom ostvaruju tradicionalan odnos, prihvaća.

\section{Druga hipoteza: Roditelji smatraju kako partnerski odnos sa školom pozitivno utječe na njihovu djecu.}

Roditeljima su ponuđene tvrdnje na koje su mogli odgovoriti 1 (ne slažem se), 2 (ni slažem se ni ne slažem se, ne znam) ili 3 (slažem se). Čak 81,9 \% roditelja smatra kako je partnerski odnos sa školom koristan za akademski uspjeh djeteta, 15,3 \% roditelja ne zna li je takav odnos koristan za akademski uspjeh djeteta, a 2,8 \% roditelja smatra kako nije koristan.

Da partnerski odnos sa školom pozitivno utječe na ponašanje djeteta u školi, smatra 84,7 $\%$ roditelja, a da ne utječe pozitivno smatra jedan roditelj $(1,4 \%)$. Niti se slaže niti se ne slaže $s$ tom tvrdnjom smatra $13,9 \%$ roditelja.

Tvrdnja da partnerski odnos obitelji i škole utječe na kvalitetniji odnos djeteta prema školi smatra $80,6 \%$ roditelja, jedan roditelj smatra da ne utječe, a 18,1\% roditelja ne zna.

$S$ tvrdnjom da partnerski odnos roditelja i škole pridonosi emocionalnom i socijalnom razvoju djeteta slaže se $66,7 \%$ roditelja, ne slaže se $2,8 \%$ roditelja, a njih $30,6 \%$ niti se slaže ni ne slaže. 


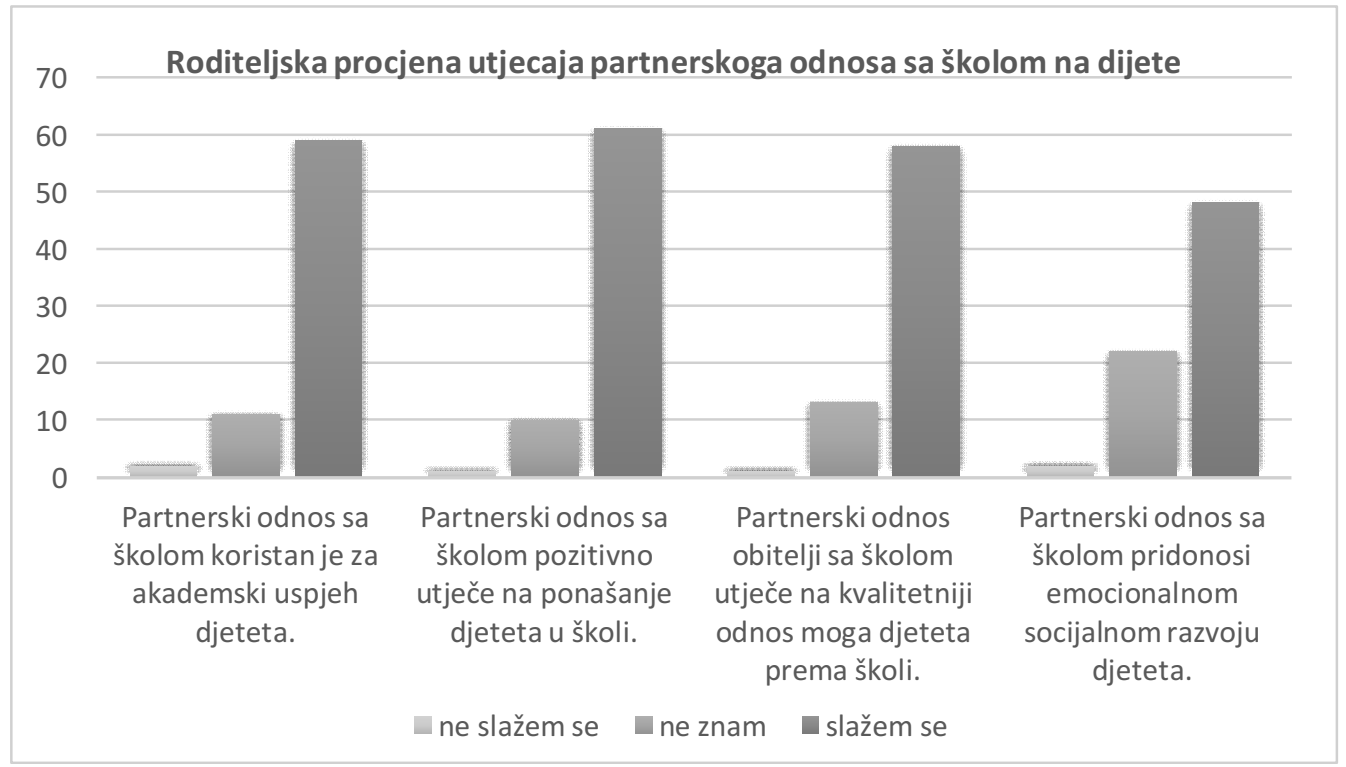

Grafikon 2. Roditeljska procjena utjecaja partnerskoga odnosa sa školom na dijete

Iz Tablice 3. može se uočiti da je prosječna vrijednost razine učinka partnerstva 2,49 (u rasponu od 1 do 3) što ukazuje na iskazanu visoku razinu slaganja s prosječnim odstupanjem od aritmetičke sredine 0,29. Riječ je o maloj varijaciji ( $V=11,46 \%$ ). Medijan vrijednost 2,50 upućuje na zaključak da je polovica roditelja imala vrijednost manju, a polovica veću ili jednaku 2,50. Interkvartil se nalazi u rasponu od 2,33 do 2,75.

Tablica 3. Razina i učinak partnerskoga odnosa obitelji i škole na učenika iz perspektive roditelja

\begin{tabular}{|c|c|}
\hline & Razina i učinak partnerstva \\
\hline $\mathrm{N}$ & 72,00 \\
\hline Prosječna vrijednost & 2,49 \\
\hline Medijan & 2,50 \\
\hline Standardna devijacija & 0,29 \\
\hline Q1 & 2,33 \\
\hline Q3 & 2,75 \\
\hline Koeficijent varijacije & $11,46 \%$ \\
\hline
\end{tabular}

Je li riječ o visokoj vrijednosti, testira se Wilcoxon testom za jedan uzorak. Empirijska p-vrijednost $(p<0,001)$ upućuje na zaključak da je iskazana razina učinka partnerstva statistički značajno veća od 2, odnosno postojana je prema mišljenju roditelja. Hipoteza se prihvaća kao istinita. 
Mirjana Knežević

\section{Treća hipoteza: Razrednici uočavaju prednosti partnerskoga odnosa s obitelji za učenike.}

Rezultati pokazuju kako $61,1 \%$ razrednika smatra da partnerski odnos s roditeljima pridonosi emocionalnom i socijalnom razvoju učenika, a 38,9 \% razrednika niti se slaže niti se ne slaže s tom tvrdnjom.

$\mathrm{S}$ tvrdnjom kako partnerski odnos s roditeljima pozitivno utječe na kvalitetniji odnos učenik prema školi slaže se $77,8 \%$ razrednika, a $22,2 \%$ ne zna utječe li partnerstvo s obitelji na odnos učenika prema školi.

Da partnerski odnos s roditeljima pozitivno utječe na ponašanje učenika u školi, smatra $88,9 \%$ razrednika, dok se samo jedan razrednik $(5,6 \%)$ s time ne slaže i jedan razrednik niti se slaže niti se ne slaže.

Značajan je i postotak razrednika koji smatraju kako je partnerstvo s roditeljima korisno za akademski uspjeh učenika (88,9\%), dok samo $11,1 \%$ razrednika nije sigurno u opravdanost te tvrdnje.

Istraživanje Steh i Kalin (2011) obuhvatilo je 448 osnovnih škola u Sloveniji, a rezultati su pokazali kako 76,8 \% učitelja smatra da je suradnja s roditeljima nužna i korisna za učenike. Dor i Rucker-Naidu (2012) proveli su istraživanje o stavovima 29 učitelja u SAD-u i 27 nastavnika u Izraelu prema uključenosti roditelja u život škole. Kada su ih pitali što misle o uključenosti roditelja u obrazovanje djece, svi su potvrdili kako je to korisno za učenje i akademski uspjeh učenika.

Iz Tablice 4. može se uočiti da je prosječna vrijednost razine učinka partnerstva 2,23 (u rasponu od 1 do 3) što ukazuje na iskazanu visoku razinu slaganja s prosječnim odstupanjem od aritmetičke sredine 0,29. Riječ je o maloj varijaciji ( $V=13,0 \%$. Medijan vrijednost 2,21 upućuje na zaključak da je polovica razrednika imala vrijednost manju, a polovica veću ili jednaku 2,21. Interkvartil se nalazi u rasponu od 2,00 do 2,35.

Tablica 4. Razina i učinak partnerskoga odnosa obitelji i škole na učenika iz perspektive razrednika

\begin{tabular}{|c|c|}
\hline & Razina i učinak partnerstva \\
\hline $\mathrm{N}$ & 18 \\
\hline Prosječna vrijednost & 2,23 \\
\hline Medijan & 2,21 \\
\hline Standardna devijacija & 0,29 \\
\hline Q1 & 2,00 \\
\hline Q3 & 2,35 \\
\hline Koeficijent varijacije & $13,0 \%$ \\
\hline
\end{tabular}

Je li riječ o visokoj vrijednosti, testira se Wilcoxon testom za jedan uzorak. P-vrijednost $(p<0,001)$ upućuje na zaključak da je iskazana razina učinka partnerstva statistički značajno veća od 2, odnosno postojana je prema mišljenju razrednika. Hipoteza se prihvaća kao istinita. 


\section{Četvrta hipoteza: Razrednici smatraju kako roditelji surađuju sa školom samo kada je to neophodno za obrazovanje njihova djeteta.}

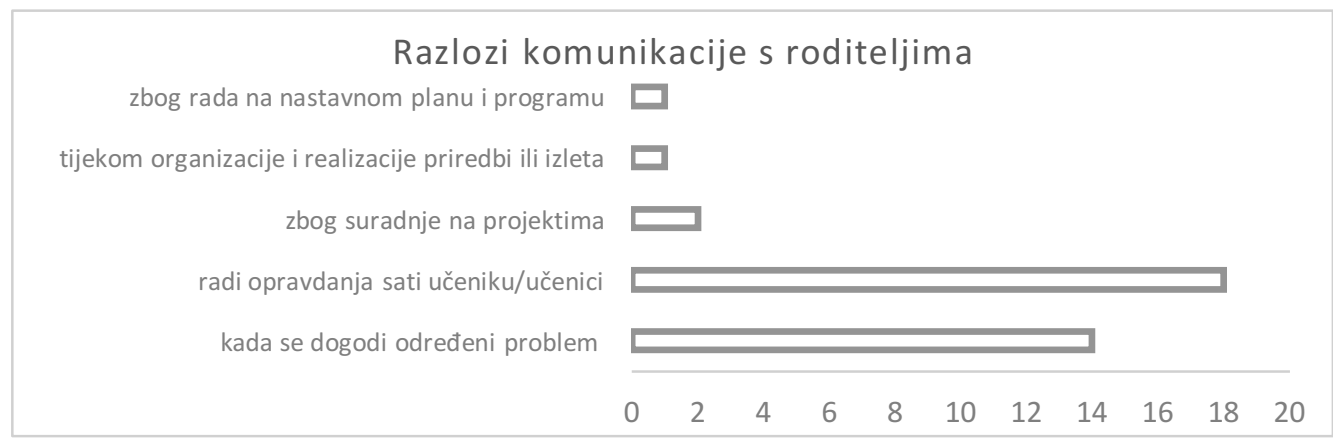

Grafikon 3. Razlozi komunikacije razrednika s roditeljima u protekloj školskoj godini

U idućem je pitanju razrednicima dano da odaberu dva najčešća razloga komunikacije $s$ roditeljima u protekloj školskoj godini. Vidljivo je kako je najčešći razlog komunikacije između razrednika i roditelja bio radi opravdavanja sati učeniku, što su zaokružili svi razrednici (100 \%), dok je drugi razlog prema zastupljenosti bio "gašenje požara“, to jest komunikacija u slučaju kada se dogodi određeni problem, a time se misli na negativne ocjene, neopravdane izostanke te probleme s ponašanjem učenika u školi, a tako se izjasnilo $77,8 \%$ razrednika. Ostali su razlozi komunikacije razrednika s roditelja: suradnja na određenim projektima $(11,1 \%)$, suradnja na organizaciji i realizaciji priredbi i izleta $(5,6 \%)$ te suradnja pri izradi nastavnoga plana i programa $(5,6 \%)$.

Ako se rezultati dobiveni ispitivanjem razrednika usporede s rezultatima dobivenim ispitivanjem roditelja, može se uočiti kako obje skupine ispitanika podjednako rangiraju ponuđene razloge komunikacije. Dakle, prvo mjesto zauzima razlog radi opravdavanja sati, a drugo mjesto kada se dogodi određeni problem. Najmanje zastupljeni razlozi komunikacije kod obje skupine ispitanika su sudjelovanje u izradi nastavnoga plana i programa, suradnja na projektima te organizacija izleta i priredbi.

Razrednicima su dane i dvije tvrdnje na koje su mogli odgovoriti 1 (ne slažem se), 2 (niti se slažem niti se ne slažem) ili 3 (slažem se), a koje izražavaju njihove stavove prema razlozima dolaska roditelja u školu.

\section{Dolasci roditelja u školu}

口 Roditelji u školu najčešće dolaze na moj poziv ili poziv stručne službe i ravnatelja.

口 Roditelji u školu često dolaze samoinicijativno kao bi razgovarali sa mnom, stručnom službom ili ravnateljem. 10

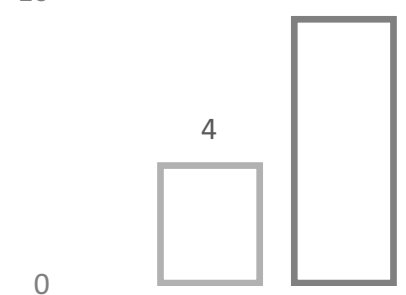

ne slažem se

9
6

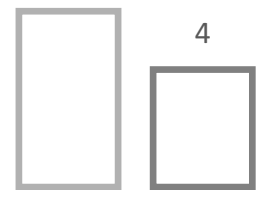

ne znam
8

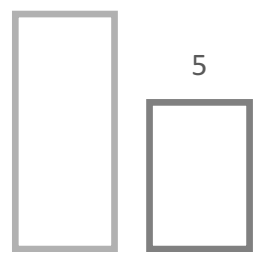

slažem se

Grafikon 4. Dolasci roditelja u školu iz perspektive razrednika 
Mirjana Knežević

Grafikon 4. prikazuje kako $44,4 \%$ razrednika smatra da roditelji dolaze u školu samo kada ih se pozove, odnosno $50 \%$ razrednika smatra kako roditelji ne dolaze samoinicijativno u školu, to jest bez njihova poziva, poziva stručne službe ili ravnatelja. Usporede li se ti rezultati s rezultatima roditelja, dobije se sličan odgovor; 56 \% roditelja smatra da najčešće u školu dolaze na poziv razrednika/ce ili stručne službe.

Testiranjem razlika u proporcijama zaključuje se da je komunikacija radi opravdavanja sati djetetu statistički značajno najučestaliji razlog. Zaključak je donesen na temelju empirijske $p$-vrijednosti $(p<0,0321)$. Visoka razina proporcije utvrđena je i za razlog kada se dogodi određeni problem. Time se hipoteza prihvaća kao istinita.

\section{Peta hipoteza: Razrednici i roditelji smatraju kako postoje teškoće za ostvarenje partnerskoga odnosa obitelji i škole.}

Proučavanjem literature došlo se do najčešćih teškoća u ostvarivanju partnerskoga odnosa škole i obitelji, a za potrebe ovoga istraživanja one su kao tvrdnje ponuđene razrednicima i roditeljima kako bi izrazili svoj stav o tim teškoćama (Tablica 5. i Tablica 6.).

Tablica 5. Stavovi razrednika o poteškoćama partnerskoga odnosa s roditeljima

\begin{tabular}{|c|l|c|c|c|}
\hline $\begin{array}{c}\text { Red. } \\
\text { br. }\end{array}$ & Sadržaj čestice & $\begin{array}{c}\text { Ne slažem } \\
\text { se }\end{array}$ & $\begin{array}{c}\text { Niti se slažem } \\
\text { niti se ne slažem }\end{array}$ & $\begin{array}{c}\text { Slažem } \\
\text { se }\end{array}$ \\
\hline 1. & $\begin{array}{l}\text { Nemam dovoljno vremena za razgovor s roditeljima jer } \\
\text { sam preopterećen/a drugim školskim obvezama. }\end{array}$ & $44,4 \%$ & $38,9 \%$ & $16,7 \%$ \\
\hline 2. & $\begin{array}{l}\text { Kada razgovaram s roditeljima, imam dojam da me ne } \\
\text { slušaju. }\end{array}$ & $55,6 \%$ & $44,4 \%$ & $0,00 \%$ \\
\hline 3. & $\begin{array}{l}\text { Dosad sam nailazio/la na roditeljsku podršku kada sam } \\
\text { htio/htjela pomoći njihovu djetetu. }\end{array}$ & $0,0 \%$ & $33,3 \%$ & $66,7 \%$ \\
\hline 4. & $\begin{array}{l}\text { Smatram da roditelji nemaju pravi utjecaj na djecu pa } \\
\text { probleme s učenicima nastojim riješiti sam/a. }\end{array}$ & $22,2 \%$ & $77,8 \%$ & $0,00 \%$ \\
\hline 5. & $\begin{array}{l}\text { Škola nema dovoljno prostora za individualne } \\
\text { razgovore s roditeljima. }\end{array}$ & $77,8 \%$ & $11,1 \%$ & $11,1 \%$ \\
\hline 6. & $\begin{array}{l}\text { Roditelji mi dolaze na individualne razgovore u vrijeme } \\
\text { kada oni nisu predviđeni pa ne mogu s njima } \\
\text { razgovarati kako bih volio/voljela. }\end{array}$ & $33,3 \%$ & $66,7 \%$ & $0,00 \%$ \\
\hline
\end{tabular}

U Tablici 5. navedeno je šest tvrdnji na koje su razrednici mogli odgovoriti 1 (ne slažem se), 2 (niti se slažem niti se ne slažem) ili 3 (slažem se). Tvrdnje se odnose na potencijalne poteškoće u ostvarivanju partnerskoga odnosa obitelji i škole. Zanimljivo je kako se čak $77,8 \%$ razrednika niti slaže niti ne slaže $s$ tvrdnjom da roditelji nemaju pravi utjecaj na djecu pa probleme s učenicima nastoje riješiti oni sami, a njih 66,7 \% niti se slaže niti ne slaže da im roditelji dolaze na individualne razgovore u vrijeme kada oni nisu predviđeni. Njih 55,6\% razrednika ne slaže se $s$ tvrdnjom da tijekom razgovora s roditeljima imaju dojam da ih ne slušaju. Gotova polovica razrednika $(44,4 \%)$ ne smatra teškoćom partnerskoga odnosa s roditeljima svoje druge školske obveze, $77,8 \%$ razrednika ne slaže se da škola nema dovoljno prostora za individualne razgovore, a njih 66,7 \% slaže se $s$ tvrdnjom da su dosad nailazili na roditeljsku podršku kada su htjeli pomoći njihovu djetetu. Dakle, 66,7 \% razrednika smatra kako navedene tvrdnje nisu poteškoće u ostvarivanju partnerskoga odnosa s obitelji, a 33,3 \% razrednika niti se slaže ni ne slaže s time. 
Tablica 6. Stavovi roditelja o poteškoćama partnerskoga odnosa sa školom

\begin{tabular}{|c|l|c|c|c|}
\hline $\begin{array}{c}\text { Red. } \\
\text { br. }\end{array}$ & \multicolumn{1}{|c|}{ Sadržaj čestice } & $\begin{array}{c}\text { Ne } \\
\text { slažem se }\end{array}$ & $\begin{array}{c}\text { Niti se slažem niti } \\
\text { se ne slažem }\end{array}$ & $\begin{array}{c}\text { Slažem } \\
\text { se }\end{array}$ \\
\hline 1. & $\begin{array}{l}\text { Nemam dovoljno vremena za posjet školi i razgovor s } \\
\text { razrednikom/razrednicom. }\end{array}$ & $12,5 \%$ & $62,5 \%$ & $25 \%$ \\
\hline 2. & $\begin{array}{l}\text { Kada dođem u školu, imam osjećaj da me razrednik/ } \\
\text { razrednica, stručna služba i/ili ravnatelj ne slušaju. }\end{array}$ & $72,2 \%$ & $20,8 \%$ & $6,9 \%$ \\
\hline 3. & $\begin{array}{l}\text { Nemam dovoljno povjerenja u razrednika/cu da bih } \\
\text { mu/joj rekao/la sve što se odnosi na dijete ili obiteljsku } \\
\text { situaciju. }\end{array}$ & $51,4 \%$ & $37,5 \%$ & $11,1 \%$ \\
\hline 4. & $\begin{array}{l}\text { Ako mi razrednik/ca kaže da moje dijete ima loše } \\
\text { ocjene, to znači da moja vrijednost kao roditelja opada. }\end{array}$ & $50 \%$ & $40,3 \%$ & $9,7 \%$ \\
\hline 5. & $\begin{array}{l}\text { Dosad sam nailazio/la na podršku razrednika/ce kada } \\
\text { sam trebao/la podršku ili riješiti određeni problem. }\end{array}$ & $0,0 \%$ & $27,8 \%$ & $72,2 \%$ \\
\hline 6. & $\begin{array}{l}\text { Često dođem na informativni razgovor s } \\
\text { razrednikom/com u vrijeme koje nije predviđeno za to. }\end{array}$ & $33,3 \%$ & $54,2 \%$ & $12,5 \%$ \\
\hline 7. & Smatram da razrednik/ca želi najbolje za moje dijete. & $1,4 \%$ & & $25 \%$ \\
\hline
\end{tabular}

Roditeljima je ponuđeno sedam tvrdnji na koje su mogli odgovoriti 1 (ne slažem se), 2 (niti se slažem niti se ne slažem) ili 3 (slažem se). Tvrdnje se također odnose na potencijalne poteškoće u ostvarivanju partnerskoga odnosa obitelji i škole. Većina roditelja $(71,4 \%)$ ne slaže se kako je ijedna od navedenih tvrdnji poteškoća u ostvarivanju partnerskoga odnosa sa školom, a 28,6 \% roditelja niti se slaže niti ne slaže da su ponuđene tvrdnje poteškoće.

Steh i Kalin (2011) istraživale su kako učitelji i roditelji ocjenjuju svoju suradnju i koji su ključni problemi te suradnje. Postavile su pitanje učiteljima i roditeljima o najvećim zaprekama za ostvarenje partnerstva između obitelji i škole. Navele su sljedeće teškoće: okrivljavanje učitelja/roditelja, nerazumijevanje, slabo međusobno poznavanje, preopterećenost učitelja, preopterećenost roditelja, loša iskustva s učiteljima/roditeljima, kritiziranje učitelja ili djece te posljednja tvrdnja da zapreka nema. Najviše je učitelja (34 \%) i roditelja (54,9 \%) reklo kako nema teškoća u odnosu škole i obitelji. Dakle, rezultati njihova istraživanja također pokazuju kako učitelji i roditelji ne vide teškoće u ostvarivanju partnerskoga odnosa škole i obitelji. Što se tiče ostalih tvrdnji, najviše je učitelja ( $27 \%$ ) kao teškoću odabralo svoju preopterećenost, a najviše roditelja $(17,1 \%)$ nedovoljno međusobno poznavanje.

S obzirom na dobivene rezultate, to jest da $66,7 \%$ razrednika, a $71,4 \%$ roditelja ponuđene tvrdnje ne smatra teškoćama partnerskoga odnosa obitelji i škole, hipoteza se odbacuje.

\section{ZAKLUČAK}

Do polovine prošloga stoljeća njegovao se tradicionalni odnos obitelji sa školom gdje su roditelji prepuštali brigu za obrazovanje djece školi, a škola nije očekivala izravnu uključenost roditelja u život škole. Međutim, jačanjem demokracije i povećanjem stupnja obrazovanosti roditelja, javlja se zahtjev za aktivnijim sudjelovanjem u obrazovanju vlastitoga djeteta. Partnerski odnos obitelji i škole pozitivno utječe na dječji emocionalni i socijalni razvoj, njegov osjećaj vrijednosti i akademski uspjeh. Takav odnos omogućuje roditeljima bolje upoznavanje vlastitoga djeteta te im daje osjećaj učinkovitosti jer pridonose dječjem razvoju. Od takvoga 
Mirjana Knežević

odnosa profitiraju i odgojno-obrazovni djelatnici jer dobivaju povratnu informaciju o svome radu. Ipak, i dalje postoje teškoće za ostvarenje takvoga odnosa, a najčešće su roditeljsko uvjerenje da njihovo dijete nema problema, nedostatak vremena, osjećaj da druga strana ne sluša, loše prethodno iskustvo, nedostatak povjerenja, sumnja da razgovor može išta promijeniti.

Istraživanje je provedeno u Ugostiteljsko-turističkoj školi u Osijeku među 18 razrednika drugih, trećih i četvrtih razreda te 72 roditelja učenika drugih, trećih i četvrtih razreda. Problem su istraživanja stavovi roditelja i razrednika o oblicima, učincima i teškoćama partnerskih odnosa između obitelji i škole, a cilj je istraživanja bio utvrditi koji oblik odnosa njeguju roditelji i razrednici, tradicionalni ili partnerski, vide li prednosti partnerskoga odnosa za djecu/učenike te smatraju li da postoje teškoće za ostvarenje partnerskoga odnosa između obitelji i škole. Istraživanjem je utvrđeno kako roditelji i dalje surađuju sa školom uglavnom na tradicionalan način na roditeljskim sastancima i individualnim razgovorima. Zanimljivo je kako najveći broj roditelja ne zna želi li sudjelovati u organizaciji školskih izleta i aktivnosti te ne znaju bi li voljeli da škola omogući više edukativnih radionica i predavanja za roditelje, a ipak u najvećoj mjeri smatraju da su dovoljno uključeni u obrazovanje svojega djeteta. Pokazatelji prevlasti tradicionalnoga pristupa dakako su i najčešći razlozi zbog kojih roditelji komuniciraju sa školom, a rezultati anketnih listova za roditelje pokazuju kako se komunikacija odvijala radi opravdavanja sati djetetu ili kada se dogodio određeni problem (negativne ocjene, neopravdani izostanci, problemi s ponašanjem), a vrlo rijetko zbog suradnje na projektima ili aktivnostima. I roditelji i razrednici vide prednosti partnerskoga odnosa obitelji i škole na dijete/učenika i to na njegov akademski uspjeh, ponašanje u školi, kvalitetniji odnos prema školi te na socijalni i emocionalni razvoj. Istraživanje je također pokazalo kako razrednici smatraju da roditelji surađuju sa školom samo kada je to nužno za obrazovanje njihova djeteta, odnosno u slučaju kada treba opravdati sate ili kada se pojave određeni problemi, a upravo su te razloge i roditelji naveli kao najčešće kada je komunikacija sa školom u pitanju. Polovica razrednika smatra da roditelji dolaze u školu samo na njihov poziv ili poziv stručne službe, a vrlo rijetko samoinicijativno. Posljednja se hipoteza odnosila na teškoće u ostvarivanju partnerskoga odnosa obitelji i škole, a rezultati su pokazali kako najveći broj roditelja i razrednika ponuđene tvrdnje nije vidio kao teškoće. Postoji mogućnost da ispitanici zaprekama smatraju teškoće koje nisu navedene, no druga istraživanja došla su do sličnih rezultata.

Dobiveni rezultati nesumnjivo pokazuju kako obitelj i škola surađuju, no još uvijek dominira tradicionalan način komunikacije. Roditelji ne vide potrebu sudjelovanja u školskim aktivnostima iako kažu da partnerski odnos sa školom pozitivno utječe na njihovo dijete. Stoga je potrebno uložiti napore kako bi se roditelje motiviralo na bolju suradnju sa školom ukazujući im na prednosti takve vrste odnosa, a odgojno-obrazovne djelatnike bolje pripremiti i podučavati iniciranju partnerstva s roditeljima. S obzirom da su objema stranama djeca, to jest učenici na prvom mjestu, jačanje partnerstva obitelji i škole nameće se kao izazov, ali i zahtjev za moderno doba u kojemu živimo. Ovim se istraživanjem otvaraju brojna pitanja koja se odnose na partnerstvo škole i obitelji. S obzirom da je istraživanje provedeno u strukovnoj školi, bilo bi zanimljivo ispitati socioekonomski status roditelja i njihovu udaljenost od škole, zatim sudjelovanje roditelja u životu škole s obzirom na uspjeh učenika te vidjeti kakvo je stanje u gimnazijama gdje su mahom akademski uspješni i ponašanjem dobri učenici. 


\section{LITERATURA}

Bronfenbrenner, U. (1986). Ecology of the family as a context for human development: Research perspectives. Developmental Psychology, 2(6), 723-7 42.

Dor, A. i Rucker-Naidu, T. B. (2012). Teachers' attitudes toward parents' involvement in school: Comparing teachers in the USA and Israel. Issues In Educational Research, 22(3), 246-262.

Epstein, J. L. (2001). School, Family and Community Partnerships: Preparing educators and improving schools. Boulder, CO: Westview.

Jukić, R. (2015). Roditelji kao sukonstruktori suvremenog kurikuluma. U: V. Buljubašić-Kuzmanović, S. Simel, S. Gazibara i K. Rengel (ur.), Znanstveno-stručni skup Partnerstvo u odgoju i obrazovanju: zbornik sažetaka plenarnih izlaganja i priopćenja (str. 11-12). Osijek: Filozofski fakultet Osijek.

Jurčević Lozančić, A. (2011). Redefiniranje odgojne uloge obitelji. Hrvatski časopis za odgoj i obrazovanje, 13(4), 122-150.

Jurčić, M. (2012). Pedagoške kompetencije suvremenog učitelja. Zagreb: Recedo.

Jurić, V. (1995). Zadovoljstvo obitelji školom. Društvena istraživanja: časopis za opća društvena pitanja, 4(4-5), 641-655.

Jurić, V. (2004). Metodika rada školskoga pedagoga. Zagreb: Školska knjiga.

Kolak, A. (2006). Suradnja roditelja i škole. Pedagogijska istraživanja, 3(2), 123-138.

Kosić, A. (2009). Roditelji i nastavnici: partneri u unapređivanju odgojno-obrazovnoga procesa u osnovnoj školi. Život i škola, 55(2), 227-234.

Lukaš, M. i Gazibara, S. (2010). Modaliteti suradničkih odnosa školskog pedagoga i roditelja. Život $i$ škola, 56(2), 210-229.

Maleš, D. (1994). Različito shvaćanje suradnje roditelja i profesionalaca. Napredak: časopis za pedagogijsku teoriju i praksu, 135(3), 342-349.

Maleš, D. (1995). Od nijeme potpore do partnerstva između obitelji i škole. Društvena istraživanja: časopis za opća društvena pitanja, 1(21), 75-88.

Mužić, V. (1999). Uvod u metodologiju istraživanja odgoja i obrazovanja. Zagreb: Educa.

Narodne novine (2010). Pravilnik o načinima, postupcima i elementima vrednovanja učenika u osnovnoj i srednjoj školi. Zagreb: Narodne novine d. d., 112 (10).

Pahić, T., Miljević-Riđički, R. i Vizek Vidović, V. (2010). Uključenost roditelja u život škole: Percepcija roditelja opće populacije i predstavnika roditelja u školskim tijelima. Odgojne znanosti, 12(2), 329-346.

Pažin-llakovac, R. (2016). Kurikulumsko partnerstvo u izgradnji odgojno-socijalne kulture škole. Doktorska disertacija. Osijek: Filozofski fakultet.

Rengel, K. i Bungić, M. (2014). Suradnja obitelji i dječjeg vrtića iz perspektive djece. U: I. Prskalo, A. L. Jurčević i Z. Braičić (ur.), 14. dani Mate Demarina: Suvremeni izazovi teorije i prakse odgoja $i$ obrazovanja (str. 221-232). Zagreb: Učiteljski fakultet, Sveučilište u Zagrebu.

Rosić, V. (2005). Odgoj, obitelj, škola. Rijeka: Žagar.

Rosić, V., Zloković, J. (2003). Modeli suradnje obitelji i škole. Đakovo: Tempo d.o.o.

Sekulić-Majurec, A. (2000). Kvantitativni i/ili kvalitativni pristup istraživanjima pedagoških fenomena - neke aktualne dvojbe. Napredak, 141(3), 289-300.

Steh, B. i Kalin, J. (2011). Building partner cooperation between teachers and parents. CEPS Journal, 1(4), 81-101.

Škutor, M. (2014). Partnerstvo škole i obitelji - temelj dječjeg uspjeha. Napredak: časopis za pedagogijsku teoriju i praksu, 155(3), 209-222.

Vujević, M. (2002). Uvođenje u znanstveni rad u području društvenih znanosti. Zagreb: Školska knjiga.

Nikčević-Milković, A. (2008). Projekt „Škola otvorena roditeljima" u cilju ostvarenja partnerstva škole i roditelja kao pretpostavke održivog razvoja. Preuzeto s https://bib.irb.hr/datoteka/791511. rad_OR.pdf,_13.7.2017. 
Teachers of the Szybinski High School in Cieszyn and Psychologists from the Psychological and Pedagogical Counselling Centre in Cieszyn. Cooperation between school and parents. Supporting the educational process. Preuzeto $s$

http://www.szybinski.cieszyn.pl/szybinski_new/sites/default/files/wsp\%C3\%B3\%C5\%82praca\%20z \%20rodzicami\%20-\%20regio\%20handout_ENGLISH_0.pdf, 11.7.2017.

\title{
Attitudes of Parents and Homeroom Teachers towards Forms, Effects and Difficulties of Family - School Partnership
}

\begin{abstract}
Family and educational institutions are dominant environments for children and therefore their partnership is necessary. While their cooperation includes the attempt to satisfy interests of both parties, the term partnership, the use of which is nowadays in increase, emphasizes the equality of both sides and tolerance. In literature relating to this subject, certain effects of that partnership are emphasized, for example, better academic success of children, better attitude of children towards school and their teachers, empowerment of the family and disburdening of children.

The goal of the empirical part was to determine the form of interaction, traditional or partnership-oriented, which is cultivated by parents and homeroom teachers. Also, the goal was to see if parents and homeroom teachers realize the advantages of the partnership-oriented interaction for children, namely students, and to examine their attitudes towards difficulties of partnership realization. The research was conducted on 72 parents and 18 homeroom teachers in September and October of 2017 in School of Hospitality and Tourism Management in Osijek. The survey procedure was used in the implementation of the research. The research data were processed using descriptive statistics. The data were shown in graphical and table form, and they were interpreted. The obtained results show that, despite the theoretical advocacy of partnership-oriented interaction, parents and homeroom teachers still practice traditional interaction even though both groups realize the advantages of partnership-oriented interaction for children / students. Also, homeroom teachers believe that parents cooperate with school only when it is absolutely necessary for the further education of their child. By examining attitudes of parents and homeroom teachers it is determined that they do not perceive difficulties encountered in partnershiporiented interaction.
\end{abstract}

Keywords: partnership, parents, homeroom teachers, students

\section{Einstellungen der Eltern und Klassenlehrer zu den Formen, Leistungen und Schwierigkeiten der partnerschaftlichen Beziehungen zwischen der Familie und Schule}

Zusammenfassung: Die Familie und Einrichtungen wie Schulen sind dominante Umfelder des Kindes und deswegen ist ihre Partnerschaft von großer Bedeutung. Während bei einer Zusammenarbeit versucht wird, die Interessen beider Seiten zu befriedigen, geht es bei einer Partnerschaft vielmehr um die Gleichberechtigung und gegenseitige Toleranz. Die Fachliteratur betont gewisse Wirkungen einer solchen Partnerschaft, wie z.B. bessere schulische Leistung der Kinder, eine bessere Beziehung der Schüler zur Schule und zu den Lehrern, ein besseres Verhältnis innerhalb der Familie und die Entlastung der Schüler.

Im empirischen Teil war das Ziel festzustellen, ob die Eltern und Klassenlehrer die traditionelle oder die partnerschaftliche Beziehung bevorzugen, ob sie Vorteile der partnerschaftlichen Beziehung für die Kinder, bzw. für die Schüler sehen und welche Einstellungen sie zu den Schwierigkeiten der Verwirklichung einer partnerschaftlichen Beziehung haben. Die Studie wurde im September und Oktober 2017 in der Gastgewerbe- und Tourismusschule in Osijek durchgeführt und es wurden 72 Eltern und 18 Klassenlehrer befragt. Während der Studie wurde die Methode der Umfrage benutzt. Die Daten wurden mit der deskriptiven Statistik ausgewertet, graphisch dargestellt und interpretiert. Die Ergebnisse haben gezeigt, dass die Eltern und Klassenlehrer trotz der theoretischen Befürwortung einer partnerschaftlichen Beziehung, weiterhin die traditionelle Beziehung praktizieren, obwohl beide Seiten die Vorteile einer partnerschaftlichen Beziehung für die Kinder/Schüler sehen. Zudem sind die Klassenlehrer der Meinung, dass 
die Eltern nur dann mit der Schule zusammenarbeiten möchten, wenn es für die Weiterbildung ihrer Kinder unentbehrlich ist. Durch das Erfragen der Einstellungen beider Seiten wurde festgestellt, dass weder die Eltern noch die Lehrer Schwierigkeiten in der partnerschaftlichen Beziehung sehen.

Schlüsselwörter: Partnerschaft, Eltern, Klassenlehrer, Schüler 